\title{
A Review of the Unemployment - Economic Growth Nexus in Nigeria from 1980 to 2015: A Disaggregated Approach
}

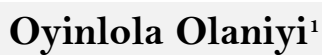 \\ Muhammad $\mathrm{Ali}^{*}$ \\ Adesanya Babatunde Moses ${ }^{3}$}

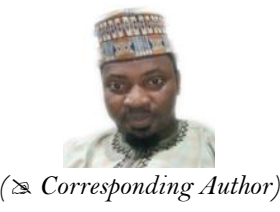

D,s Department of Economics University of Abuja, Abuja, Nigeria.

'Email:Oyinlola.olanivi@uniabuja.edu.ng Tel: +23483735650

Email: almuhad94@yahoo.com Tel: +2348067654291

${ }^{9}$ Email: mosestunde2012@gmail.com Tel: +2348066503596

\section{Abstract}

The phenomenon of jobless growth in Nigeria in recent years has called to question the Okun's law that the growth of gross domestic product (GDP) reduces unemployment. This study therefore, analyses the nexus between GDP growth and unemployment in Nigeria by disaggregating total output into its sectoral components to analyze the impact of sectoral output on unemployment using data from 1980 to-2015 employing the econometric technique of Autoregressive Distributed Lag (ARDL) bound testing approach. Two ARDL models were specified. The first bound test revealed the existence of co integration between unemployment and GDP growth. The growth of GDP is positively related to unemployment in the long run but a negative relationship was found in the short run. The result of the disaggregated model (i.e the second ARDL model) found no long run relationship between unemployment and agriculture, industry, construction, trade, and services. We opined that the findings of the disaggregated model resulted from the disconnection between aggregate demand and aggregate supply of the productive sectors and the lack of direct linkages between the oil sector and other sectors of the economy. The study recommends that such linkages should be forged through enhanced funding of research and development, technological innovation and the development of value chain of agriculture and solid minerals output. Nigerians should be encouraged to consume locally made products. Efforts should be intensified to develop direct linkages between the oil sector and other sectors through input supply contracts and the development of downstream industries in the oil sector.

Keywords: Industrial growth, Economic Growth, Unemployment, Okun’s law, ARDL, Nigeria

Citation | Oyinlola Olaniyi; Muhammad Ali; Adesanya Babatunde Moses (2021). A Review of the Unemployment - Economic Growth Nexus in Nigeria from 1980 to 2015: A Disaggregated Approach. Growth, 8(1): 48-56.

History:

Received: 27 September 202

Revised: 22 October 2021

Accepted: 19 November 202

Published: 8 December 2021

Licensed: This work is licensed under a Creative Commons

Attribution 3.0 License $(\mathrm{cc}) \mathbf{E Y}$

Publisher: Asian Online Journal Publishing Group
Acknowledgement: All authors contributed to the conception and design of the study.

Funding: This study received no specific financial support.

Competing Interests: The authors declare that they have no conflict of interests.

Transparency: The authors confirm that the manuscript is an honest, accurate, and transparent account of the study was reported; that no vital features of the study have been omitted; and that any discrepancies from the study as planned have been explained.

Ethical: This study follows all ethical practices during writing.

\section{Contents}

1. Introduction

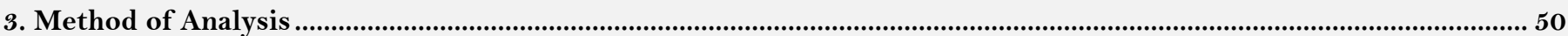

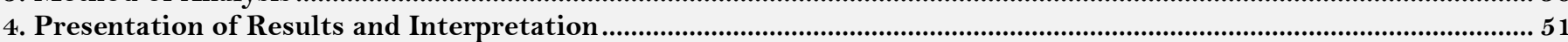

References. 


\section{Contribution of this paper to the literature}

This study contributes existing literature by investigating the effect of Nigeria's economic structure on unemployment with output disaggregated into its major components.

\section{Introduction}

Unemployment and its derivatives which include erosion of human capital, social exclusion, wide spread poverty, increased crime rates and high rates of morbidity are major economic and social problems that should attract the attention of every policy maker and analyst. Hence all hands should be on deck to facilitate easy resolution of unemployment problems anywhere in the world. However, unemployment has been a problem in Nigeria since the 1980 s and rather than abate, it has continued to increase in spite of efforts by successive governments to bring it under control. Though the Okun (1962) predicts a negative relationship between economic growth and unemployment, and it is true for many developed economies (e.g. (Christopoulos, 2004; Daniels \& Ejara, 2009)) recent studies in some developed and developing countries show that the relationship is not predictable as presented (Gutierrez, Orecchia, Paci, \& Serneels, 2007; Hull, 2009; Loayza \& Raddatz, 2010) etc, Also, empirical findings in Nigeria have revealed that Okun's law does not hold in the economy (Akeju \& Olanipekun, 2015; Arewa \& Nwakanma, 2012; Babalola et al., 2013). Furthermore, Ajakaiye et al. (2016) observed the existence of jobless growth in Nigeria. They found that the average growth rate in the decade before 2016 was 6.8 per cent but the rate of unemployment grew at a compound annual average of 4.8 per cent, even as it has continued to fluctuate and intensify since 2000 (Ajakaiye et al., 2016). According to Akeju and Olanipekun (2015) the rate is higher in the rural areas (25.6 percent) than in the urban areas (17.1 percent) in spite of high performance in crop production which in Nigeria, is a predominantly rural activity. Ajakaiye et al. (2016) observed that the growth periods 2005- 2009 and 2010 - 2014 were accompanied by a 7.37 per cent and 5.93 per cent reduction in employment respectively. The reduction in employment effect of output growth has been attributed to technical changes resulting in the substitution of capital for labour which has intensified in Nigeria since the year 2000 (Ayinde, Adekunle, \& Muritala, 2018). According to Ajakaiye et al. (2016) labour productivity increased by 29.5 and 5.93 per cent during the growth periods 2005 - 2009 and $2010-2014$ respectively. Could this be the reason for the rising trend of unemployment in Nigerian or the problem is structural? In other words, is the rising unemployment in Nigeria the result of the structural composition of the economy, the labor force structure or due to low output or declining aggregate demand?

Most of the previous attempts made to analyze the unemployment economic growth nexus (i.e Okun's Law) in Nigeria, (e.g. (Adudu \& Ojonye, 2015; Babalola et al., 2013; Florence et al., 2015; Njoku \& Ihugba, 2011)) generally focused attention on aggregate output. This focus on aggregate output alone presupposes that unemployment in Nigeria is a problem emanating from low or declining aggregate output. This presumes that unemployment in Nigeria is a cyclical problem which does not take into account differences in sectoral intensity of job creation as it does not reveal the relationship between sectoral growth and unemployment. This may lead to poor policy prescription and policy ineffectiveness. Only Ajakaiye et al. (2016) to the best of our knowledge examined a disaggregated effect of growth on employment generation in Nigeria. The study used the World Bank stepwise decomposition approach and time series variables were employed with total output disaggregated into manufacturing, services and agricultural sectors. However, they neither conducted unit root tests on the variables nor examined the short-run and long-run effects of output growth on employment.

This is the gap this study intends to fill. The study has not only investigated the effect of Nigeria's economic structure on unemployment by disaggregating output into its major components, it has also analyzed short-run and long-run effects of output growth on unemployment. Time series data spanning 1980-2015 was used and unit roots test was conducted on the variables. Total output was disaggregated into agriculture, industry, construction, trade, and services to investigate their respective impacts on unemployment. The rest of the paper is divided into four sections. Section 2 is on literature review and section 3 is on research methodology. In section 4 the results are presented and interpreted while section 5 is the summary and conclusion section.

\section{Literature Review \\ 2.1. Conceptual Revierw}

\subsubsection{Concept of Unemployment}

Unemployment may be defined as the existence of members of a country's workforce (i.e. those aged between 15 and 65) who are able and willing to work at the current wage rate but cannot find a job (Kale \& Doguwa, 2015). There are many types of unemployment. These include frictional unemployment, cyclical unemployment, seasonal unemployment, technological unemployment, structural unemployment and hidden unemployment. Frictional unemployment is the unemployment that occurs when an individual changes his place of residence or occupation. This can arise even when the economy is in full employment hence a zero level of unemployment may never be achieved. Cyclical unemployment is created by reduction in job opportunities when the volume of production i.e. aggregate output reduces. This is the type of unemployment that arises when effective demand is low compared to the production volume leading to a rise in the inventory of finished goods which makes employers to lay off their workers. Seasonal unemployment is the unemployment that is associated with occupations whose activities fluctuate with seasons either because production activities are weather dependent like agriculture and construction or demand for such service is seasonal like in tourism. Technological unemployment is due to technical changes that result in the replacement of workers by machines. It occurs with advances in methods of production or innovation in organizational practices. Structural unemployment occurs when the economy is at a stagnant level in all or some of its sectors. It can also be the result of a mismatch between the general structure of labor demand and labor supply arising from inappropriate labor force structure or poor geographical distribution of occupations, skills and industry. Hidden unemployment refers to a situation where people who seemingly participate in the production process do not have any contribution to production, that is, their marginal productivity is zero (Soylu, Çakmak, \& Okur, 2018). 


\subsubsection{Concept of Economic Growth}

Economic growth may be defined as increase in the size of economic activities and thereby the amount of goods and services produced in a country over time (Jhingan, 2005). This translates into growth in income per capita if the increase in the size of economic activities or revenue therefrom is higher than increase in population whereby the average individual is able to access a higher quantity and or quality of good and service for consumption. However, increase in gross the value of product emanating from a temporary rise in the price of a primary commodity may not lead to increase in productive activities that provide more opportunities for sustainable employment. Hence economic growth refers to the increase over time, in the economy's capacity to produce the goods and services needed to improve the wellbeing of its citizens in increasing numbers and diversity (Anyanwu \& Oaikhenan, 1995). Economic growth therefore generally refers to sustained increase in the aggregate level of output of an economy and its main indicator is a rising gross domestic product (GDP). This sustainability may be achieved through more efficient or intensive use of some or all the factors of production leading to increase in the total factor productivity. This may be called intensive growth and it could be employment inelastic (i.e. result in jobless growth) particularly if the sector involved does not have direct linkages with other sectors in the economy. Economic growth may also be the result of an increase in the utilization of one or more factors of production leading to extensive growth. It is when growth in output is the result of extensive use of factors of production that it becomes employment elastic and may follow the Okun's co-efficient.

\subsection{Theoretical and Empirical Review of the Unemployment Growth Nexus}

Since Keynes pointed to the link between aggregate demand, level of output and unemployment the in the 1930s economists have generally agreed that unemployment is caused by lack of aggregate demand leading to decline in the gross domestic product (GDP). Hence to prevent wide spread unemployment, the level of output must keep growing. However, Okun (1962) is the first to statistically establish a relationship between change in the unemployment rate and economic growth. He estimated his equation using quarterly data of GDP in the US economy from 1947 to 1960 and found a 3:1 negative relationship between GDP and unemployment. He concluded that if GDP grows rapidly, the unemployment rate declines, if growth is very low or negative, the unemployment rate rises and if growth rate equals the growth of potential output, unemployment rate would remain the same. Okun (1962) however added that these depend on workforce participation rate, duration of work and change in productivity. Khemraj, Madrick, and Semmler (2006) updated the Okun's result for the US economy with data from 1961 to 2000. They obtained GDP and employment elasticities using panel model analysis and found a declining response of jobs to growth in output. Their result shows that the Okun's coefficient for the US economy has changed giving rise to the phenomenon of jobless growth in US. This they observed was not the case in other countries like Germany and France where the coefficient was rising. The result shows that the Okun's relationship is not static but it changes between time and from one country to another depending on the structure of production and technology in use.

Gutierrez et al. (2007) using a sample of growth spells in 39 countries, concluded that the sectoral growth pattern and employment/productivity profile vary significantly among countries. The study concludes that sectoral pattern of employment generation and productivity growth, are key determinant factors of the rate of unemployment. Hence the relationship between output growth and unemployment is no longer as simplistic as it was in the first half of the twentieth century. Loayza and Raddatz (2010) found that growth in unskilled -intensive sector contributed to poverty reduction by providing better jobs. However, in Nigeria poverty rate increased with greater intensity in the rural sector than the urban sector in spite of higher growth in crop production (Akeju \& Olanipekun, 2015) an unskilled-intensive and predominantly a rural activity.

Onaran (2008) conducted country specific panel data analysis for manufacturing industry in eight central and eastern American countries and found that unemployment was completely de-linked from output mostly in medium and low skilled sectors. Haider (2010) also conducted a sectoral analysis of employment demand in Pakistan and found that jobless growth exists only in the manufacturing sector because the manufacturing sector in Pakistani required a higher threshold level of economic growth. However, the World Economic Forum (2014) opines that jobless growth is often the characteristic of an economy with technology derived job replacement.

In the case of Nigeria, Olotu, Salami, and Akeremale (2015) observed that jobless growth is as a result of the country's inability to fully utilize available factors of production hence the country produces a large number of graduates each year but this is not matched by the economy's capacity to absorb them. On the other hand Ajakaiye et al. (2016) found that the main reason for 'jobless growth' in Nigeria is that the economy is transforming from an agrarian economy to a service economy without going through the intermediate stage of industrialization. The questions to which this study is addressed are; a) what is responsible for this unusual economic transformation from agriculture to service sectors and b) what limits the absorptive capacity for labour in the economy? The study adapts the theoretical framework of the Okuns model to analyze the nexus between output and unemployment in Nigeria.

\section{Method of Analysis}

The method employed in carrying out the study is presented here as follows:

\subsection{Model Specification}

The econometric models used for the study is adapted from Ajakaiye et al. (2016) and are specified as follows:

$$
U N E M P_{t}=\beta_{o}+\beta_{1} \operatorname{In} G D P_{t}+U_{t}
$$$$
U N E M P_{t}=\beta_{o}+\beta_{1} \operatorname{In} A G R_{t}+\beta_{2} \operatorname{InIND}_{t}+\beta_{3} \operatorname{InCONS_{t}}+\beta_{4} \operatorname{InTRADE} E_{t}+\beta_{5} \operatorname{InSERVS} S_{t}+U_{t}
$$

Where UNEMP $=$ Unemployment rate

$\beta_{\mathrm{o}} \quad=$ Constant parameter

$\beta_{\mathrm{i}} \quad=$ Coefficients of the explanatory variables

$\operatorname{lnGDP}_{\mathrm{t}}=\log$ of gross domestic product 
$\operatorname{lnAGR}_{\mathrm{t}}=\log$ of agricultural output

$\operatorname{lnIND}_{\mathrm{t}}=\log$ of industrial output

$\operatorname{lnCONS} S_{t}=\log$ of construction sector's output

$\ln$ TRADE $_{t}=\log$ of trade

$\operatorname{lnSERVS}_{\mathrm{t}}=\log$ of services sector's output

$\mathrm{U}_{\mathrm{t}} \quad=$ Stochastic disturbance term

$\mathrm{t}=$ Time subscript

Equations 1 and 2 were employed as models for this research.

\subsection{Data}

This research used annual data sourced from the Central Bank of Nigeria Statistical Bulletin (Central Bank of Nigeria, 2016) and National Bureau of Statistics (NBS) financial and external sector statistics for the period 19802015 (National Bureau of Statistics, 2015). The 36-year period is selected to meet the requirement of the Central Limit Theorem that a sample size must not be less than thirty years for normality purpose, and that the larger the sample, the greater the reliability or validity of time series research findings (Gujarati, 2005).

\subsection{Variables}

Unemployment rate is used as the dependent variable as it best reveals the labour force engagement; the data on it are easily accessible, and it is also considered appropriate in view of the theoretical underpinning of the study.

The independent variables are the GDP, agricultural output, industrial output, construction, services sector, and trade.

\subsection{Method of Data Analysis}

The data collected for this research were analysed using Autoregressive Distributed Lag (ARDL) model along with error correction model. The ARDL model is an innovation in time series econometrics developed by Pesaran and Shin (1996) for testing the existence of co-integration among variables. One of the advantages of using the ARDL approach to test for the existence of a long-run relationship between variables is that it is applicable irrespective of whether the underlying variables are purely $\mathrm{I}(0)$ or $\mathrm{I}(1)$, or a mixture of both (Khosravi \& Karimi, 2010). However, in the presence of $\mathrm{I}(2)$ variables, the computed F-statistics provided by Pesaran, Shin, and Smith (2001) will become invalid. Hence the inevitability of unit root tests in the ARDL approach to ensure that none of the variables is integrated of order I $(2)$ or beyond. The unit root test was conducted using the Augmented DickeyFuller (ADF) technique based on the model expressed in equation 3.

$\Delta \mathrm{Y}_{\mathrm{t}}=\beta_{\mathrm{o}}+\beta_{1} \mathrm{Y}_{\mathrm{t}-1}+\alpha_{\mathrm{i}} \Sigma \Delta \mathrm{Y}_{\mathrm{t}-\mathrm{i}}+\mathrm{u}_{\mathrm{t}}$

Where: $\quad \triangle_{\mathrm{t}} \quad=$ Differenced value of a given time series variable

$\beta_{0}=$ Constant Parameter

$\beta_{1}=$ Coefficient of the first lag value of the series variable

$\mathrm{Y}_{\mathrm{t}-1}=$ First lag value of a series variable

$\alpha_{i}=$ Coefficient of the lag values of the differenced time series variable

$\mathrm{Y}_{\mathrm{t}-\mathrm{i}}=\triangle \mathrm{ag}$ values of the differenced series variable

$\mathrm{u}_{\mathrm{t}}=$ Error term.

The two Autoregressive Distributed Lag (ARDL) models used in this study are expressed as follows: ARDL I

$\triangle \mathrm{InUNEMP}=\delta_{0}+\delta_{1} \operatorname{InUNEMP}_{\mathrm{t}-1}+\delta_{2} \operatorname{InGDP}_{\mathrm{t}-1}+\sum \lambda_{1} \Delta \operatorname{InUNEMP}_{\mathrm{t}-\mathrm{i}}+\sum \lambda_{2} \Delta \operatorname{InGDP}_{\mathrm{t}-\mathrm{i}}+\lambda_{3} \mathrm{ECM}_{\mathrm{t}-1}+\mathrm{u}_{\mathrm{t}} \ldots \ldots(4)$ ARDL II

$\triangle \mathrm{UNEMP}=\delta_{0}+\delta_{1} \operatorname{InUNEMP}_{\mathrm{t}-1}+\delta_{2} \mathrm{InAGR}_{\mathrm{t}-1}+\delta_{3} \operatorname{InIND}_{\mathrm{t}-1}+\delta_{4} \operatorname{InCONS}_{\mathrm{t}-1}+\delta_{5} \operatorname{InTRADE}_{\mathrm{t}-1}+\delta_{6} \operatorname{InSERVS}_{\mathrm{t}-1}+$ $\sum \lambda_{1} \Delta \operatorname{InUNEMP}_{\mathrm{t}-\mathrm{i}}+\sum \lambda_{2} \Delta \operatorname{InAGR}_{\mathrm{t}-\mathrm{i}}+\sum \lambda_{3} \Delta \mathrm{InIND}_{\mathrm{t}-\mathrm{i}}+\sum \lambda_{4} \Delta \operatorname{InCONS}_{\mathrm{t}-\mathrm{i}}+\sum \lambda_{5} \Delta \operatorname{InTRADE}_{\mathrm{t}-\mathrm{I}}+\sum \lambda_{6} \Delta \operatorname{InSERVS}_{\mathrm{t}-\mathrm{i}}+$

$\lambda_{7} \mathrm{ECM}_{\mathrm{t}-1}+\mathrm{u}_{\mathrm{t}}$

Where $\delta_{0}=$ Constant Parameter

$\Delta \quad=$ First difference operator

$\delta_{\mathrm{i}}, \lambda_{\mathrm{i}}=$ Vector of the parameter of the lagged values of the natural logarithmic values of the explanatory variables.

$\mathrm{ECM}_{\mathrm{t}-1}=$ Error correction term

$u_{\mathrm{t}}$

$=$ Error term

The terms with the summation signs $\left(\sum\right)$ in the equations 4 and 5 above represent the error correction dynamics (short-run relationship) while the second part of the equation with $\delta_{\mathrm{i}}$ correspond to the long-run relationship. The null hypothesis in the four ARDL equations is $\mathrm{H}_{0}=\mathrm{a}_{1}=\mathrm{a}_{2}=\mathrm{a}_{3}=0$. This denotes the absence of long-run relationship while the alternative hypothesis is $\mathrm{H}_{1}: \mathrm{a}_{1} \neq \mathrm{a}_{2} \neq \mathrm{a}_{3}=0$. The calculated $\mathrm{F}$-statistic is compared with two sets of critical values. One set assumes that all the variables are I(0) and the other assumes they are I(1). If the calculated $\mathrm{F}$ - statistic exceed the lower and upper critical value, the null hypothesis of no co-integration will be rejected irrespective of whether the variables are $\mathrm{I}(0)$ or $\mathrm{I}(1)$. If it is below the upper value bound, there is no cointegration.

Once a co-integration relationship has been ascertained the long-run and short run parameters of the relationship are then estimated.

\section{Presentation of Results and Interpretation}

The findings of the study are presented as follows.

\subsection{Unit Root Test Results}

The outcome of the unit root tests using the Augmented Dickey Fuller (ADF) test presented in Table 1 reveals that all the variables satisfy this condition. As a first step in the analysis, the explanatory variables were 
transformed into natural logarithm form. Table 1 shows that services and construction industries' output were stationary at level $\mathrm{I}(\mathrm{O})$ while unemployment, gross domestic product (GDP), and the outputs of agriculture, industry, and trade, were stationary after first difference. This is because in absolute term, the t-test statistic values of the variables examined were found to be significantly greater than their critical values. While the test statistic values of the variables were either significant at $1 \%, 5 \%$, or $10 \%$ as the case may be. This implies that none of the series is I(2). Therefore, all the variables may be included in the ARDL estimation.

\begin{tabular}{c|c|c|c|c}
\multicolumn{5}{c}{ Table-1. Unit Root Tests Results. } \\
\hline & & \multicolumn{2}{c}{ ADF Unit Root Test } & \\
\hline Variables & Critical Values & At level I(0) & Critical Values & At First Difference I(1) \\
\hline UNEMP & & & -4.309824 & $-6.63094^{* * * *}$ \\
\hline InGDP & & & -4.252879 & $-8.566993^{* * * *}$ \\
\hline InAGR & & & -4.252879 & $-4.447399^{* * * *}$ \\
\hline InIND & & & -4.252879 & $-5.681937^{* * * *}$ \\
\hline InSERVS & -3.207094 & $-3.347718^{*}$ & & \\
\hline InCONS & -4.252879 & $-6.074624 * * *$ & & $-3.701722^{* * *}$ \\
\hline InTRADE & & & -3.548490 & \\
\hline Note: **** Statistical significance at 1\% level; ** statistical significance at $5 \%$; * Statistical significance at $10 \%$
\end{tabular}

\subsection{Regression Results}

The ARDL estimation was done using the two different models specified above. It begins by examining the relationship between unemployment and GDP (i.e., ARDL I), followed by the relationship between unemployment on one hand and agriculture, industry, construction, trade, and services on the other hand (ARDL II). The two different models were estimated to analyze the economic growth and unemployment nexus at the aggregate and sectoral levels in the Nigerian economy. Also, maximum of two lag lengths were considered to reduce the problem of degree of freedom.

In each of the ARDL procedures examined, the optimum lag length selection criteria were carried out in order to determine the number of lag(s) to be included in the ARDL models prior to the bound test. The results are presented in Table 2 , and Table 6.

Table-2. Lag Length Selection for ARDL I Model.

\begin{tabular}{c|c|c|c}
\hline Lag & AIC & SC & HQ \\
\hline 0 & 5.962659 & 6.054267 & 5.993024 \\
\hline 1 & 5.043673 & 5.279414 & 4.984641 \\
\hline 2 & 4.882824 & 5.215875 & 4.984641 \\
\hline
\end{tabular}

From Table 2, the Akaike Information Criterion (AIC), and Shwarz Criterion (SC) indicate that two maximum lags are to be included in the ARDL I model.

Table-3. ARDL Bounds Test for Cointegration (ARDL I Model).

\begin{tabular}{c|c|c}
\hline \multicolumn{2}{c}{ Dependent Variable: $\triangle$ UNEMP } & $8.454559^{* * *}$ \\
\hline Function & & Upper Bound \\
\hline F(UNEMP/InGDP & Lower Bound & 4.14 \\
\hline Critical Value & 3.17 & 4.85 \\
\hline $1 \%$ & 3.79 & 6.36 \\
\hline $5 \%$ & 5.15 &
\end{tabular}

Note: *** Statistical significance at $1 \%$ level; ** statistical significance at $5 \%$;

* Statistical significance at $10 \%$

Critical values are obtained from Pesaran et al. (2001).

Having conducted the unit root test and the optimum lag selection, F-statistic test for cointegration is required to determine whether there is cointegration among the variables captured in the unrestricted error correction version of the ARDL I model. This has been estimated using the bound testing approach and the results presented in Table 3.

From Table 3, the bound test results reveal the existence of a long run relationship between unemployment and GDP. In the function $\mathrm{F}(\mathrm{UNEMP} / \mathrm{lnGDP})$, the null hypothesis that there is no cointegration is rejected at $1 \%$ level as the F-statistic, 8.454559 is greater than the critical value, 4.14, at the upper bound indicating that there is cointegration between unemployment and GDP. Next step is to examine the long run impacts of GDP growth on unemployment in Nigeria using OLS technique.

Table-4. Estimated Long Run Coefficients of ARDL I Model.

\begin{tabular}{|c|c|c|}
\hline \multicolumn{2}{|c|}{ Dependent Variable: UNEMP } & \multirow[b]{2}{*}{ P-values } \\
\hline Independent Variables & Coefficients & \\
\hline $\mathrm{C}$ & $-16.68093^{* * * *}$ & 0.0000 \\
\hline InGDP & $3.281959^{* * * *}$ & 0.0000 \\
\hline \multicolumn{2}{|c|}{$\mathrm{R} 2=0.695924 \quad$ F-Statistic $=68.65963(0.000000)$} & \\
\hline \multicolumn{2}{|c|}{ Durbin-Watson Statistic $=1.943290$} & \\
\hline
\end{tabular}

We estimate the long run equilibrium relationship between the variables using OLS. From the results as reported in Table 4, it reveals that GDP growth is positively related to unemployment in Nigeria in the long-run, and the result is statistically significant at $1 \%$. This negates the postulation of the Okun's law which states that 
there is negative relationship between economic growth and unemployment. The coefficient of determination $\left(\mathrm{R}^{2}\right)$ is 0.695924 . The result shows that $70 \%$ of variation in unemployment rate is caused by variation in the explanatory variable. The Durbin Watson statistics is 1.943290 which shows the absence of serial correlation as it is close to 2 . The F-statistic (68.65963) is significant at $1 \%$ which means that the model is adequate. Thus, growth in GDP is implicated in the long run trend of unemployment which has followed a rising path since the 1980s. This could not have been caused by shocks arising from technical changes alone.

Table-5. Results of Estimated Short Run Coefficients of the Selected ARDL I Model.

\begin{tabular}{c|c|c}
\hline \multicolumn{2}{c}{ Dependent Variable: $\Delta \mathrm{UNEMP}$} & \\
\hline Independent Variables & Coefficients & P-values \\
\hline $\mathrm{C}$ & $6.375586^{* * *}$ & 0.0006 \\
\hline$\Delta \operatorname{InUNEMP}(-1)$ & -0.146975 & 0.3981 \\
\hline$\Delta \operatorname{InUNEMP}(-2)$ & 0.001895 & 0.9908 \\
\hline$\Delta \operatorname{InGDP}(-1)$ & $-10.19356^{*}$ & 0.0758 \\
\hline$\Delta \operatorname{InGDP}(-2)$ & $-17.38017^{* * *}$ & 0.0081 \\
\hline $\mathrm{ECT}(-1)$ & $-0.567536^{* * *}$ & 0.0005 \\
\hline
\end{tabular}

Note: *** Statistical significance at $1 \%$ level; ** statistical significance at $5 \%$;

* Statistical significance at $10 \%$

The result of the short run relationship is estimated and reported in Table 5. The error correction coefficient $(\mathrm{ECT}(-1))$ which is approximately -0.57 not only has the expected negative sign but it is also statistically significant at $1 \%$ considering the probability value which is 0.0005 . The value of the ECT $(-1)$ implies a fairly high speed of adjustment to equilibrium after a shock. Approximately $57 \%$ of disequilibria from the previous year's shock converge back to the long-run equilibrium in the current year. For the explanatory variable, the differenced one period and two period lag values of GDP show the existence of significant negative relationship between economic growth and unemployment at $10 \%$ and $1 \%$ levels respectively. This means that the economic growth and unemployment relationship follows the Okun's law in the short run in Nigeria.

\begin{tabular}{c|c|c|c}
\multicolumn{4}{|c}{ Table-6. Lag Length Selection for ARDL II Model. } \\
\hline Lag & AIC & SC & HQ \\
\hline 0 & 5.171571 & 5.446397 & 5.262668 \\
\hline 1 & 5.189700 & 5.802626 & 5.381661 \\
\hline 2 & 5.209209 & 6.113205 & 5.485569 \\
\hline
\end{tabular}

We estimated the ARDL II model to investigate whether there is long run relationship between unemployment, agriculture, industry, construction, trade, and services. The procedure starts with the optimum lag length selection criteria as reported in Table 6. Based on Akaike Information Criterion (AIC) Shwarz Criterion (SC), and Hanna-Quinn Criterion (HQ), one lag length was selected.

Table-7. ARDL Bounds Test for Cointegration (ARDL II Model)

\begin{tabular}{|c|c|c|}
\hline \multicolumn{2}{|c|}{ Dependent Variable: $\triangle \mathrm{UNEMP}$} & \\
\hline Function & F-Statistics & \\
\hline \multicolumn{2}{|c|}{ F(UNEMP/InAGR,InIND, InCONS, InTRADE,InSERVS) } & 1.283452 \\
\hline Critical Value & Lower Bound & Upper Bound \\
\hline $1 \%$ & 3.41 & 4.68 \\
\hline $5 \%$ & 2.62 & 3.79 \\
\hline $10 \%$ & 2.26 & 3.35 \\
\hline
\end{tabular}

Critical values are obtained from Pesaran et al. (2001). Source: Authors' computation using E-views 9.

From Table 7, the bound test results reveal that there is no long run relationship between unemployment, agriculture, industry, construction, trade, and services sectors growth as the F-statistic, 1.283458 is less than all the critical values at the upper and lower bounds. Hence, we could not go further to estimate the long run coefficients and speed of adjustment of the variables to long run equilibrium.

Since there is no long-run relationship among the variables in the system above, we then stop here as further regression will present spurious results. The above results reveal structural defects in the economy which account for the so called 'tertiarization' of the Nigerian economy. The growth periods $2005-2009$ and $2010-2014$ used by Ajakaiye et al. (2016) to arrive at the conclusion that the economy is transforming from agriculture to tertiary sectors without passing through the traditional stages of industrialization, are also oil boom periods (see Table 8 , Figure 1). In 2004 the price of crude oil rose by 28.3 per cent from US $\$ 28$ to US\$36.05. The rise continued until 2008 when the price of crude oil rose to US $\$ 94.1$ before it fell to US $\$ 60.9$ in 2009 . However, with the commencement of the Arab spring in 2010, the price of OPEC crude oil went up again as it increased to US $\$ 77.4$ in 2010, US\$97.5 in 2011 and picked at US\$105.9 in 2012 before declining marginally to US\$105.9 and 96.3 in 2014. In 2015 it slumped to US $\$ 49.5$ which led to the so-called economic recession. Thus, during periods 2004 to 2009 and 2010 to 2014 the growth in national income merely mirrored the increases in oil revenue arising from increased oil prices. This does not necessarily imply increase, in the economy's productive capacity that normally facilitates increase in employment opportunities. Growth in oil revenue may be interpreted as more efficient utilization of factors in the oil sector (intensive growth) but this may not be unemployment reducing if the oil sector does not have effective linkages with other productive sectors in the economy as is the case in Nigeria. The Nigeria oil sector is an enclave sector. 
Table-8. Average Annual Price of Crude Oil 2000 to 2015

\begin{tabular}{c|c|c}
\hline Year & Average Annual Price of Selected OPEC Crude Oil in US \$ & \% change in crude oil price \\
\hline 2000 & 27.6 & -16.2319 \\
\hline 2001 & 23.12 & 5.363322 \\
\hline 2002 & 24.36 & 15.35304 \\
\hline 2003 & 28.1 & 28.29181 \\
\hline 2004 & 36.05 & 40.24965 \\
\hline 2005 & 50.56 & 20.64873 \\
\hline 2007 & 61 & 13.11475 \\
\hline 2008 & 69 & 36.37681 \\
\hline 2009 & 94.1 & -35.3241 \\
\hline 2010 & 60.86 & 27.14427 \\
\hline 2011 & 77.38 & 38.87309 \\
\hline 2012 & 107.46 & 1.851852 \\
\hline 2013 & 109.45 & -3.2709 \\
\hline 2014 & 105.87 & -9.04883 \\
\hline 2015 & 96.29 & -48.6032 \\
\hline
\end{tabular}

Increased oil revenue leads to increased government revenue as oil revenue accrue mainly to government and multinational companies. In the absence of sterilization policy, it results in increased government expenditure which raises aggregate demand for consumers and durable goods and services. However, due to structural rigidities in the economy, the productive sectors are not able to adjust production levels to meet the new level of aggregate demand during an oil boom hence, importation of goods and services increase to satisfy the additional demand. Thus, it is mainly activities relating to importation and distribution goods and services that increase.

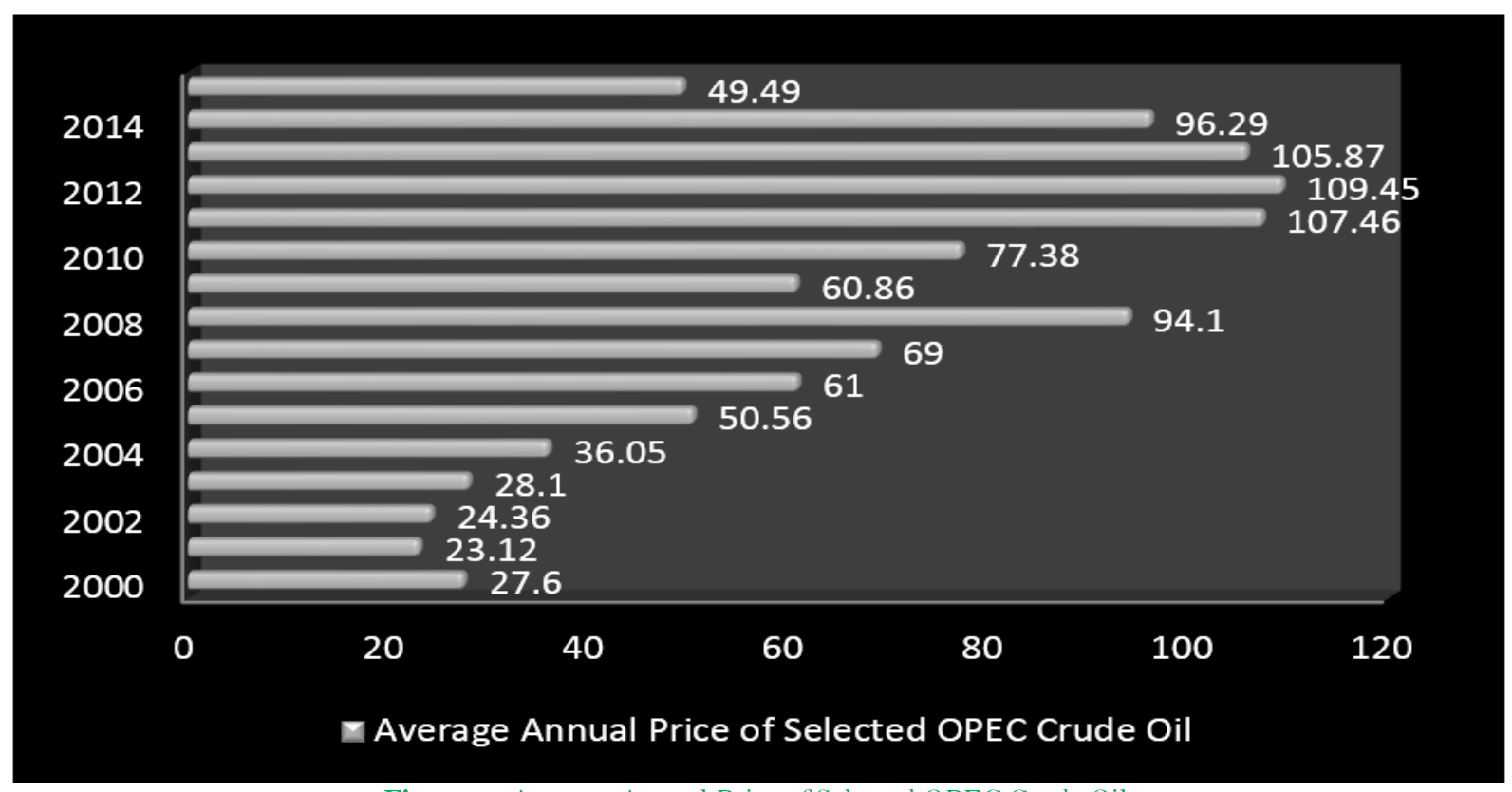

Figure-1. Average Annual Price of Selected OPEC Crude Oil.

Hence more employment is generated in the tertiary sectors like retail and wholesale trading and construction than in manufacturing and agriculture as observed by Ajakaiye et al. (2016) and termed 'tertiarization' of the economy. This also results in the fairly high speed of adjustment to equilibrium after a shock (i.e.ECT(-1) of -0.57) as the economy does not follow the normal process of adjustment whereby higher demand leads to higher investment and higher production before equilibrium is achieved. However, employment opportunities generated in trading and construction activities are not sustainable. They disappear once aggregate demand falls due to reduction in oil prices, reductions in oil revenue and reduction in government expenditure. In the long run however, successive oil booms increase the taste of Nigerians for foreign goods and services thereby replacing domestic goods and services in the consumption set leading to lose of jobs in the domestic economy. Hence the results of the ARDL I indicate that aggregate output is unemployment reducing in the short run but increases unemployment in the long run. Also, the lack of co integration and therefore no long run relationship among the variables in the ARDL II model underscores the lack of effective linkage between the source of intensive growth (oil sector) and other productive sectors like manufacturing, agriculture and solid minerals. In addition, the inability of domestic supply to meet up with aggregate demand during periods of oil booms or economic growth render the sectors incapacitated and unable to respond to job creation opportunities created by economic growth. Hence there is no co integration and no lung run relationship among them. This observed delinking of unemployment and output levels is consistent with the findings of Onaran (2008). 
The study examined the stability tests for the first ARDL model that indicate long run relationship among the variables used (i.e. ARDL I). We relied on cumulative sum (CUSUM) test and the results are presented below.

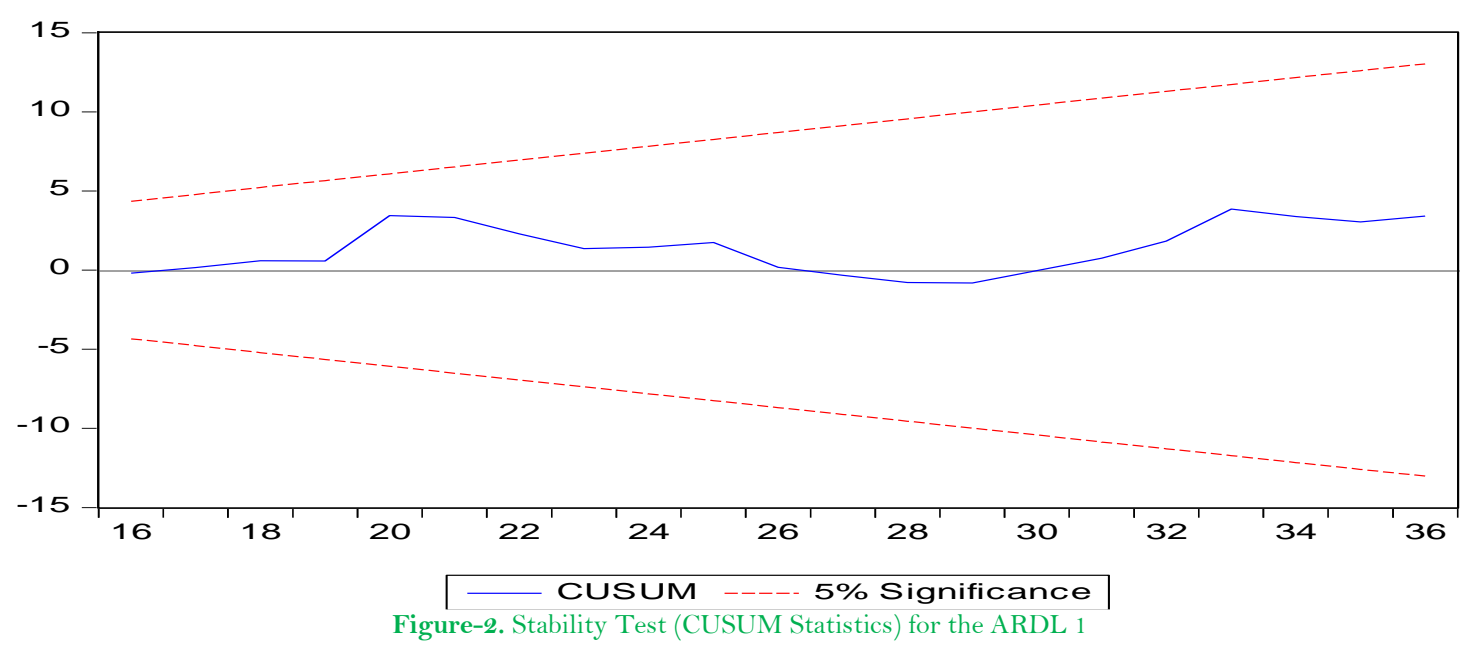

Figure 2 plots the CUSUM statistics for the ARDL I equation that revealed the existence of cointegration. It can be seen in the figure that the plot of the CUSUM stays within the critical $5 \%$ bounds which confirms the long run relationship among the variables and thus shows the stability of the ARDL I model.

\section{Summary and Conclusion}

This paper investigates relationship between economic growth and unemployment in Nigeria by first examining the relationship between aggregate GDP and unemployment, and further investigating the relationship between sectoral components of GDP and unemployment. We applied ARDL bound testing, OLS and error correction model (ECM) in the analysis and also used CUSUM to test the stability of the model used, and it was found that the ARDL I was stable. Also, the trend of OPEC oil prices from 2000 to 2001 was analyzed. The results of the unit root tests indicated that the variables are of mixed stationarity properties i.e. $\mathrm{I}(0)$ and $\mathrm{I}(1)$. The cointegration results show that there is long-run relationship between GDP and unemployment but no long-run relationship between unemployment in Nigeria and sectoral components of the GDP. The error correction model for ARDL I examined revealed a relatively high speed of adjustment to equilibrium. From the OLS results on GDP and unemployment, it was revealed that Nigeria's economic growth is positively related to unemployment in the long-run, while growth in the short-run is unemployment reducing. This shows that the jobs created through economic growth in the short-run are generally temporary and non-sustainable but employment reducing in the long run.

The result underscores the fact that economic growth in Nigeria is largely driven by the oil sector. During oil boom years, money supply grows with increases in government expenditure so does the level of aggregate demand. However, due to the structural deficiencies in the productive sectors of the economy, domestic output does not rise to match the increase in aggregate demand which is usually satisfied by increased consumption of imported consumer and durable goods. This increases employment in the service sectors mainly due to increases in wholesale and retail trade of imported items, construction and entertainment activities. However, because these consumption activities are not related to the production structures in the economy whereby aggregate consumption in Nigeria would be linked to increases in domestic production of goods and services with substantial value addition in the economy, it does not result in sustainable employment in the long run. Rather more jobs are lost when consumption of foreign goods replace that of domestic goods and services in the future. Hence in the long run the unemployment- GDP nexus is positive meaning the growth is not just jobless it reduced employment. This is because consumption of domestic output is replaced by consumption of more foreign goods during successive oil boom cycles. The findings of the long run growth-unemployment relationship is consistent with other studies in Nigeria conducted by Babalola et al. (2013); Arewa and Nwakanma (2012); Akeju and Olanipekun (2015).

On the disaggregated component of GDP, the findings revealed no long-run relationship as earlier stated. This is because there is no inter-sectoral linkage in the Nigerian economy in the form of an input-output framework that could result in high labour force participation rate. The agricultural sector suffers from neglect and the industrial sector is faced with competition from foreign goods and reliance on imported raw materials, while construction sector relies on foreign technology. The trade sector is dominated by importation which shifts employment abroad. As a result, both human and material resources are underutilized and the Nigerian economy cannot generate enough quality jobs to absorb the graduates it produces annually. To address these problems, efforts should be intensified on creating effective linkages between the oil sector and the rest of the economy through input supply from the domestic economy and forward integration to develop the downstream of the industry. Also, structural rigidities in the economy that prevent the productive sectors from taking advantage of increase in aggregate demand during oil boom periods should be affectively tackled and resolved. This includes removing the infrastructural deficit in electricity, roads, rail and water transportable. Increased funding of research and development to create innovative products that can compete with foreign goods in the consumption set of Nigerians using the country's cultural diversity in arts and artifacts. Increasing investment in the agricultural and solid mineral sectors and developing the value chain of their products and linking them to the manufacturing sectors of the economy. 


\section{References}

Adudu, S., \& Ojonye, S. M. (2015). Employment-real wage relationship and economic growth in Nigeria. Journal of Economics and Sustainable Development, 6(2), 179-188.

Ajakaiye, O., Jerome, A. T., Nabena, D., \& Alaba, O. A. (2016). Understanding the relationship between growth and employment in Nigeria. Retrieved from https://www.brookings.edu/wp-content/uploads/2016/07/growth-employment-nigeria-ajakaiye-jerome-nabenaalaba.pdf.

Akeju, K. F., \& Olanipekun, D. B. (2015). Unemployment and economic growth in Nigeria. International Journal of African and Asian Studies, $11(1), 92-98$.

Anyanwu, J. C., \& Oaikhenan, H. E. (1995). Modern macroeconomics theory and applications in Nigeria. Onitsha: Joanie Educational Publisher Ltd.

Arewa, A., \& Nwakanma, P. (2012). Potential-real GDP and growth process of Nigerian economy: An empirical re-evaluation of Okun's law. European Scientific Journal, 8(9), 25-33.

Ayinde, T. O., Adekunle, O. A., \& Muritala, A. T. (2018). Economic growth and sustainable employment generation: Empirical validation of Okun's law in Nigeria. Journal of Management, Economics and Industrial Organization, 2(2), 33-59. Available at: https://doi.org/10.31039/jomeino.2018.2.2.2.

Babalola, S. J., Saka, J. O., \& Adenuga, I. A. (2013). The validity of Okun's law in Nigeria: A difference model approach. Asian Economic and Financial Review, 3(12), 1598.

Central Bank of Nigeria. (2016). Statistical bulletin. Abuja: CBN Press.

Christopoulos, D. K. (2004). The relationship between output and unemployment: Evidence from Greek regions. Papers in Regional Science, 83(3), 611-620. Available at: https://doi.org/10.1111/j.1435-5597.2004.tbo1928.x.

Daniels, K. N., \& Ejara, D. D. (2009). Impact of information asymmetry on municipal bond yields: An empirical analysis. American Journal of Economics and Business Administration, 1(1), 11-20. Available at: https://doi.org/10.3844/ajebasp.2009.1 1.20.

Florence, A. C., Justine, I. C., \& Uchenna, U. (2015). Youth unemployment and labour productivity in Nigeria: The nexus. Journal of Research and Development, 2(8), 14-28. Available at: https://doi.org/10.12816/0017360.

Gujarati, D. N. (2005). Basic econometrics (Fifth Reprint ed.). New Delhi: Tata MacGraw Hill.

Gutierrez, C., Orecchia, C., Paci, P., \& Serneels, P. (2007). Does employment generation really matter for poverty reduction? Working Paper No. 4432, World Bank,Washington, DC.

Haider, A. (2010). Sectoral analysis of employment demand (Jobless Growth) in Pakistan: Sobey School of Business, Department of Economic, Saints Mary's University, Canada. Retrieved from: http://www.researchgate.net.

Hull, K. (2009). Understanding the relationship between economic growth, employment and poverty reduction. In Promoting Pro-Poor Growth: Employment. Paris: OECD.

Jhingan, M. L. (2005). The economics of development and planning. New Delhi: Vrinda Publishing.

Kale, Y., \& Doguwa, S. I. (2015). On the compilation of labour force statistics for Nigeria. CBN Journal of Applied Statistics, 6(1), $183-198$.

Khemraj, T., Madrick, J., \& Semmler, W. (2006). Okun's law and jobless growth” policy note. New York: Schwartz Centre for Economic Policy Analysis, the New School.

Khosravi, A., \& Karimi, M. S. (2010). To investigation the relationship between monetary, fiscal policy and economic growth in Iran: Autoregressive distributed lag approach to cointegration. American Journal of Applied Sciences, 7(3), 415-419. Available at: https://doi.org/10.3844/ajassp.2010.415.419.

Loayza, N. V., \& Raddatz, C. (2010). The composition of growth matters for poverty alleviation. Journal of Development Economics, 93(1), 137151. Available at: https://doi.org/10.1016/j.jdeveco.2009.03.008.

National Bureau of Statistics. (2015). Presentation of labour statistics based on revised concepts and methodology for computing labour statistics in Nigeria. Retrieved from www.nigerianstat.gov.ng/pages/download/285. [Accessed 28th February, 2017].

Njoku, A., \& Ihugba, O. A. (2011). Unemployment and Nigerian economic growth (1985-2009). Paper presented at the Proceedings of the 2011 International Conference on Teaching, Learning and Change, International Association for Teaching and Learning (IATEL).

Okun, A. M. (1962). Potential GNP: Its measurement and significance. Paper presented at the American Statistical Association, Proceedings of the Business and Economics Statistics Section.

Olotu, A., Salami, R., \& Akeremale, I. (2015). Poverty and rate of unemployment in Nigeria. International Journal of Management and Business, $2(1), 1-2$.

Onaran, O. (2008). Jobless growth in the Central and East European countries: A country-specific panel data analysis of the manufacturing industry. Eastern European Economics, 46(4), 90-1 15. Available at: https://doi.org/10.2753/eee0012-8775460405.

Pesaran, H. M., \& Shin, Y. (1996). Autogressive distributed lag modeling to cointegration analysis. DAE Working Paper Series, No 9514, Department of Applied Economics, University of Cambridge.

Pesaran, H., Shin, Y., \& Smith, R. J. (2001). Bound testing approach to the analysis of level relationships. Journal of Applied Econometrics, $16(3), 289-326$.

Soylu, Ö. B., Çakmak, İ., \& Okur, F. (2018). Economic growth and unemployment issue: Panel data analysis in Eastern European Countries. Journal of International Studies, 1 1(1), 93-107. Available at: https://doi.org/10.14254/2071-8330.2018/11-1/7.

World Economic Forum. (2014). Prospects for reaping a demographic dividend in Nigeria'. A case study by the world economic forum's global agenda council on population growth. Prom http://www3.weforum.org/docs/GAC/2014/WEF_GAC_NigeriaCaseStudy_2014.pdf. 